\title{
Mémoire.
}

\section{CHARACTERIZATION AND ECOLOGY OF MOSQUITO SPIROPLASMAS FROM ATLANTIC BIOTOPES IN FRANCE}

\author{
F. LE GOFF*, M. MARJOLET**, J. GUILLOTEAU***, \\ I. HUMPHERY-SMITH, C. CHASTEL
}

SUMMARY

Field studies on the ecology of mosquito spiroplasmas (Mollicutes) were carried out on a number of swampy biotopes along the Atlantic coast of France and the banks of the Loire River (Loire-Atlantique). Spiroplasma sabaudiense and the Cantharis spiroplasma were isolated from Aedes detritus and Ae. caspius during May and June 1988 but disappeared in August and September.
These data confirm the results of previous surveys performed in Savoia, Northern Alps, among other species of mosquitoes. It is possible that mosquitoes acquire their spiroplasma infections during the spring from flowers following their emergence and not from their aquatic environment.

\section{RÉsumé : Caractérisation et écologie des spiroplasmes de moustiques isolés à partir de biotopes atlantiques en France.}

L'écologie des spiroplasmes de moustiques (Mollicutes) a été étudiée dans un certain nombre de biotopes marécageux de la côte atlantique française et des bords de la Loire. Spiroplasma sabaudiense et le spiroplasme de Cantharis sp. ont été isolés à partir d'Aedes detritus et d'Ae. caspius pendant les mois de mai et juin 1988, mais ont disparu en août et septembre de la même année.
Ces résultats confirment ceux qui ont été précédemment obtenus au cours d'enquêtes réalisées en Savoie, dans les Alpes du Nord, avec d'autres espèces de moustiques. Il est possible que les moustiques acquièrent au printemps leur infection à spiroplasme au contact de fleurs peu après leur émergence et non directement à partir de leur environnement.

\section{INTRODUCTION}

Spiroplasmas are helical, motile, wall-free prokaryotes (class Mollicutes) parasitizing plants, insects and ticks, and classified in groups according to their serological affinities (Tully et al., 1987). These organisms were only recently identified from mosquitoes. The first isolation of a mosquito spiroplasma (msp) was reported from Aedes sollicitans collected in New Jersey (Slaff and Chen, 1982). Ae. sollicitans is a salt marsh mosquito which may act as a vector for a number of highly pathogenic arboviruses including Eastern Equine Encephalitis virus in USA (Karabatsos, 1985).

Since then new msp have been isolated from other mosquitoes collected in Savoia, France (Chastel et al., 1985, 1987), Taïwan (Clark et al., 1987) and Alabama, USA (Shaikh et al., 1987).

At present, three species of msp have been fully described: Spiroplasma culicicola, group X, from USA (Hung et al., 1987), S. sabaudiense, group XIII, from France

* Département de Microbiologie et Santé Publique, Faculté de Médecine, B. P. 815, F 29285 Brest Cedex.

** Service de Parasitologie et Pathologie exotique, Faculté de Médecine, F 44035 Nantes.

*** Entente interdépartementale pour la démoustication du littoral atlantique, Saint-Crépin, F 17380 Tonnay-Boutonne.

Accepté le : 6 juillet 1990 .
(Abalain-Colloc et al., 1987) and S. taiwanense, group XXII from the Far East (Abalain-Colloc et al., 1988). Another species (or complex of serovars), the Cantharis spiroplasma, group XVI, is being described. It has been isolated in USA and France from Cantharis beetles, Monobia wasp, Photinus firefly and mosquitoes, and also from a flower, the thistle (Circium sp.) (Shaikh et al., 1987; Chastel et al., 1987, 1990). Many other isolates from mosquitoes remain insufficiently characterized but may represent new, undescribed species.

Up until now, ecological studies have been restricted to France, in Alpine biotopes of Savoia were at least 5 species of mosquitoes (Aedes, Coquillettidia richiardii) have been found infected by $S$. sabaudiense and/or the Cantharis spiroplasma (Chastel et al., 1987, 1990).

In order to complete our data on msp ecology in France, field studies were extended to new mosquito species from swampy biotopes located along the Atlantic coast of France, in the vicinity of La Baule and Nantes.

\section{MATERIAL AND METHODS}

\section{Collections of mosquitoes}

Specimens were collected in the " Loire-Atlantique " district from the following locations: 
- May 1988: La Turballe, Le Bassin du Mes and Asserac, near La Baule (salt marshes);

- June 1988: La Turballe and Asserac;

- August 1988: La Turballe;

- September 1988: Passay l'Héronière and Passay-le-Plessis (Lac de Grand-Lieu) and Couëron along the banks of the Loire river, near Nantes.

Mosquitoes were collected by aspiration from human or animal bait or by using an entomological sweep net in vegetation. After anaesthesia the specimens were identified, put individually in plastic tubes and frozen in dry ice during their transportation to the laboratory of Parasitology in Nantes. Here they were stored at $-70^{\circ} \mathrm{C}$. In addition, a number of nymphs were removed from « Le Bassin du Mes " (May 9, 1988) and allowed to emerge as imagos in the laboratory. They were then processed in the same manner as imagos caught directly in the field.

Subsequently, all-specimens were transferred in dry ice to the virus laboratory in Brest and processed by msp assays.

A total of 1,067 mosquitoes specimens were tested for msp and other mycoplasmas.

\section{Isolation and characterization of msp}

The classical SP4 medium (Tully et al., 1977) containing Penicillin, $100000 \mathrm{U} / \mathrm{ml}$ (SP4), was used throughout the study for both isolation an characterization procedures of $\mathrm{msp}$.

Each mosquito was processed individually. First, an external washing was performed in $2 \mathrm{ml}$ of SP4 and the washing product was removed and filtered through a $0.45 \mu \mathrm{m}$ Millipore membrane. The same specimen was then carefully ground in a chilled mortar with $2 \mathrm{ml}$ of SP 4 and the suspension was filtered at $0.45 \mu \mathrm{m}$. Both filtered washing products and extracts, undiluted and diluted $1: 10$, were incubated at $30^{\circ} \mathrm{C}$ in SP4-for ten days in plastic culture tubes. The acidification of the medium was indicative of the possible development of a mollicute. Positive culture was confirmed by dark field microscopy showing the presence of helical organisms or the once blind passaged.

The isolates were cloned on solid SP4 medium and helical microorganisms were identified using the deformation test and hyperimmune rabbit sera prepared against reference spiroplasma strains, according to Williamson, Whitcomb and Tully (1978).

The identification of non-helical mycoplasmas (probable acholeplasmas) isolated from mosquitoes during this study was not attempted.

\section{RESULTS}

The results of msp isolation attempts from 1,067 specimens are presented in table I. Aedes detritus, Ae. caspius and Anopheles maculipennis comprised the bulk of mosquito species examined, while "miscellaneous " included Culiseta annulata, C. subochrea, C. morsitans, Culex pipiens, Anopheles claviger, Aedes vexans, Aedes sp.

Eleven isolates of msp were obtained: one of $S$. sabaudiense from an Aedes detritus female caught in May 1988 and 10 of Cantharis spiroplasma from 8 Ae.detritus females and one from both a male and a female of Ae. caspius, all caught in June 1988. No msp was isolated from mosquitoes collected in August and September 1988, including 424 specimens of An. maculipennis. Furthermore, two non-helical mycoplasmas were obtained in June from females of both Ae. detritus and Ae. caspius.

All isolates came from filtered extracts of mosquitoes and not from the corresponding washing products.

No isolation occurred from 70 imagos of both males or females of Ae. detritus, Ae. caspius and Culex pipiens processed after emergence of nymphs in the laboratory.

\section{DISCUSSION}

From biotopes located in the "Loire-Atlantique » district, no spiroplasma other than those previously found in Savoia, France, was recovered, i. e. S. sabaudiense and the Cantharis spiroplasma.

However, the prevalence of spiroplasmas in mosquitoes could appear quite different in the two areas. Only one isolate of $S$. sabaudiense was obtained from $356 \mathrm{Ae}$. detritus caught in the field, showing an " actual isolation rate» (AIR) of $1: 356$ or $0.28 \%$, far from the AIR of the same spiroplasma in Aedes sticticus in Savoia, $11: 41$ or $26.8 \%$

TABLE I. - Mosquito spiroplasmas isolated in 1988.

\begin{tabular}{|c|c|c|c|c|c|c|c|}
\hline & & \multicolumn{2}{|c|}{$\begin{array}{c}\text { May } 1988 \\
\text { (Sp. sabaudiense) }\end{array}$} & \multirow[t]{2}{*}{$\begin{array}{c}\text { June } 1988 \\
\text { (Cantharis spiroplasma) }\end{array}$} & \multirow{2}{*}{$\begin{array}{l}\text { August } 1988 \\
\text { Catching }\end{array}$} & \multirow{2}{*}{ September 1988} & \multirow[b]{2}{*}{ Total } \\
\hline & & Catching & After emerging & & & & \\
\hline Aedes detritus & $\begin{array}{l}O^{\prime} \\
\wp\end{array}$ & $\begin{array}{l}0 / 38 \\
1 / 37\end{array}$ & $\begin{array}{l}0 / 5 \\
0 / 23\end{array}$ & $\overline{8 / 205}$ & $\overline{0 / 57}$ & $\overline{0 / 19}$ & $\begin{array}{l}0 / 43 * \\
9 / 341\end{array}$ \\
\hline Aedes caspius & $\begin{array}{l}O^{\prime} \\
q\end{array}$ & $\overline{-}$ & $\begin{array}{l}0 / 28 \\
0 / 13\end{array}$ & $\begin{array}{l}1 / 1 \\
1 / 53\end{array}$ & $\overline{0 / 95}$ & $\overline{0 / 41}$ & $\begin{array}{l}1 / 29 \\
1 / 202\end{array}$ \\
\hline An. maculipennis & $q$ & - & - & - & - & $0 / 424$ & $0 / 424$ \\
\hline Miscellaneous & $\begin{array}{l}\text { O’ } \\
\text { q }\end{array}$ & $\frac{0 / 1}{-}$ & $\overline{0 / 1}$ & $\begin{array}{l}0 / 1 \\
0 / 8\end{array}$ & - & $\begin{array}{l}0 / 1 \\
0 / 16\end{array}$ & $\begin{array}{l}0 / 3 \\
0 / 25\end{array}$ \\
\hline Total & & $1 / 76$ & $0 / 70$ & $10 / 268$ & $0 / 152$ & $0 / 501$ & $11 / 1,067$ \\
\hline
\end{tabular}

* Number of isolated spiroplasmas/number of tested mosquitoes. 
(Chastel et al., 1990). The difference is highly significant $\left(\mathrm{x}^{2}=79.03 ; p<0.001\right)$.

On the contrary, the Cantharis spiroplasma was isolated from two species of mosquitoes, Ae. detritus (AIR $=8 / 356$ or $2.25 \%$ ) and Ae. caspius (AIR $=2 / 190$ or $1.05 \%$ ). These two mosquito species represent new hosts for the Cantharis spiroplasma which have been isolated previously from Aedes cantans, Ae. cinereus, Ae. sticticus, Ae. rusticus and Coquillettidia richiardii in Savoia (Chastel et al., 1987, 1990 and unpublished results) and from other mosquitoes in Alabama (Shaikh et al., 1987).

An important fact already established in Savoia (Chastel et al., 1990) is that all isolates were obtained from filtered extracts of mosquitoes and not from the corresponding washing products. This clearly indicates that these organisms originate from the internal tissues of the mosquitoes and not from their integuments (external contamination).

Another interesting finding was the first observation of a msp isolated from a male mosquito. During ecological studies of our group in Savoia (1985-1988) spiroplasma was never isolated from a male mosquito in spite of testing 1,257 specimens (unpubl. results).

On the other hand, no isolations were made from 70 imagos following emergence in the laboratory of wild caught nymphs, confirming our previous observations made in Northern Alps (Chastel et al., 1987). This reinforces our opinion that msp are probably acquired in nature by mosquitoes, including females (Magnarelli, 1978), after feeding on the nectar of flowers and not from the water at breeding sites before or during the emergence of imagos (Chastel et al., 1990). Moreover, there is no proof that spiroplasmas may survive in surface waters at least in their helical form; congenital (vertical) transmission also appears improbable because no msp was isolated in Savoia from $500 \mathrm{Ae}$. stiticus larvae (Chastel et al., 1990).

Concerning the population dynamics of msp, the present study also confirmed a number of published or unpublished data established in Savoia: msp circulate broadly from May-June to August and disappear rapidly in AugustSeptember. This represents another argument in favour of the hypothesis that msp are acquired in nature by mosquito populations from flowers during the summer. This may represent the natural cycle of Cantharis spiroplasma (Chastel et al., 1990).

The mechanisms of acquiring the msp by mosquito, of spreading the spiroplasmas among mosquitoes and of invading the mosquito body remains unknown, although the digestive route is the most probable mode of invasion as in other insects. To date, we have no explanation for the disappearance of $\mathrm{msp}$ in the late summer, nor for the manner in which msp survive during fall and winter (in insects, plants, cool- or warm-blooded vertebrates?).

Another fascinating problem about msp concerns the potential effects of the infection on the physiology and life-span of mosquitoes. Since of the first description of a msp (S. culicicola) from Ae. sollicitans by Slaff and Chen (1982), it was postulated that the spiroplasma could possibly modify the vector competence of this mosquito for Eastern Equine Encephalitis virus. This is also true for other mosquito species, other viruses and other pathogens as well. The inoculation of msp into mosquitoes significantly reduced their survival time and this may lead to their field use in mosquito control (unpublished results).

In Europe, Ae. detritus is not known as an arbovirus vector but at least three arboviruses, Tahyna, Issyl-Kul and Isfahan, have been already isolated from Ae. caspius in the Palearctic region (Karabatsos, 1985). However, the low AIR of the Cantharis spiroplasma found during this study $(0.9 \%)$, if confirmed from other areas, may prevent any significant role of this msp on the vector competence of Ae. caspius (for Tahyna virus, for instance).

Thus, msp appear as very interesting organisms, parasiting many different species of mosquitoes worldwide and the study of their ecology deserves attention, especially in view of their potential as biological control agents directed against mosquito vectors.

Acknowledgments. - This work was supported in parts by grants from INSERM, Paris (CRE 85.80.08), DRET, Paris (Contracts 86/067 and 89-230) and Fondation Langlois, Rennes, France.

\section{REFERENCES}

Abalain-Colloc M. L., Chastel C., Tully J. G., Bove J. M., Whitcomb R. F., Gilot B., Williamson D. L. : Spiroplasma sabaudiense sp. nov. from mosquitoes collected in France. Int. J. Syst. Bacteriol., 1987, 37, 260-265.

Abalain-Colloc M. L., Rosen L., Tully J. G., Bove J. M., Chastel C., Williamson D. L. : Spiroplasma taiwanense sp. nov. from Culex tritaeniorhynchus mosquitoes collected in Taiwan. Int. J. Syst. Bacteriol., 1988, 38, 103-107.

Chastel C., Gilot B., Le Goff F., Gruffaz R., Abalain-Colloc M. L. : Isolement de spiroplasmes en France (Savoie, Alpes du Nord) à partir de moustiques du genre Aedes. C. R. Acad. Sci. Paris, série III, 1985, 300, 261-266.

Chastel C., Devau B., Le Goff F., Simitzis-Le Flohic A. M., Gruffaz R., Kerdraon G., Gilot B. : Mosquito spiroplasmas from France and their ecology. Isr. J. Med. Sci., 1987, 23, 683-686.

Chastel C., Gilot B., Le Goff F., Devau B., Kerdraon G., Humphery-Smith I., Gruffaz R., Simitzis-Le Flohic A. M. : New developments in the ecology of mosquito spiroplasmas. Zentralbl. Bakteriol. Hyg., 1990, suppl. 20, 455-460.

Clark T. B., Henegar R. B., Rosen L., Hackett K. J., Whitcomb R. F., Lowry J. E., Saillard C., Bove J. M., Tully J. G., Williamson D. L. : New spiroplasmas from insects and flowers: isolation, ecology, and host association. Isr. J. Med. Sci., 1987, 23, 687-690.

Hung S. H. Y., Chen T. A., Whitcomb R. F., Tully J. G., Chen Y. X. : Spiroplasmas culicicola sp. nov. from the salt marsh mosquito Aedes sollicitans. Int. J. Syst. Bacteriol., 1987, 37, 365-370.

Karabatsos N. : International catalogue of arboviruses (third edit.). Am. Soc. Trop. Med. Hyg., San Antonio (Texas), 1985. 
Magnarelli L. A. : Nectar-feeding by female mosquitoes and its relation to follicular development and parity. J. Med. Entomol., $1978,14,527-530$.

Shaikh A. A., Johnson W. E., Stevens C., Tang A. Y.: The isolation of spiroplasmas from mosquitoes in Macon County, Alabama. J. Amer. Mosq. Contr. Assoc., 1987, 3, 289-295.

Slaff M., Chen T. A. : The isolation of a spiroplasma from Aedes sollicitans (Walker) in New Jersey. J. Fla. Anti-Mosq. Assoc., 1982, 53, 19-21.

Tully J. G., Whitcomb R. F., Clark H. F., Williamson D. L. :
Pathogenic mycoplasmas: cultivation and vertebrate pathogenicity of a new spiroplasma. Science, 1977, 195, 892-894.

Tully J. G., Rose D. L., Clarke E., Carle P., Bove J. M., Henegar R. B., Whitcomb R. F., Colflesh D. E., Williamson D. L. : Revised group classification of the genus Spiroplasma (Class Mollicutes), with proposed new groups XII to XXIII. Int. J. Syst. Bacteriol., 1987, 37, 357-364.

Williamson D. L., Whitcomb R. F., Tully J. G. : The spiroplasma deformation test, a new serological method. Curr. Microbiol., 1978, 1, 203-207. 